УДК 005.932:339.1

DOI: 10.15673/fie.v13i3.2129

\author{
Нікішина О.В. \\ доктор економічних наук, \\ старший науковий співробітник \\ завідувач відділу ринкових механізмів та структур \\ E-mail: ksenkych@gmail.com \\ ORCID ID: 0000-0002-7172-3551
}

\author{
Тараканов М.Л. \\ кандидат економічних наук, \\ старший науковий співробітник \\ відділ ринкових механізмів та структур \\ E-mail: tarakanovnikolajleonidovic@gmail.com \\ ORCID ID: 0000-0002-3827-2373
}

\author{
Зеркіна 0.0. \\ кандидат економічних наук, доцент, \\ здобувачка відділу ринкових механізмів та структур \\ Інститут проблем ринку та економіко-екологічних досліджень НАН України \\ Французький бульвар, 29, м. Одеса, Україна, 65044 \\ E-mail: oksana27@i.ua \\ ORCID ID: 0000-0002-2500-3959
}

\title{
ІНСТИТУЦІЙНА СКЛАДОВА РЕГЛАМЕНТАЦІЇ ТОВАРОРУХУ В СИСТЕМІ ТОВАРНИХ РИНКІВ*
}

У статті розроблено теоретичні засади формування інституційного базису регламентації процесу товароруху в системі товарних ринків. Визначено концептуальний підхід до регламентації товароруху, який враховує особливості взаємозв'язків між ланками ринкових логістичних ланцюгів на етапі опису товароруху, досягнення стандартів товароруху, визначення шляхів використання стандартів товароруху. На етапі опису запропоновано комплексний підхід з охопленням технологічного, економічного та організаційного рівнів відносин між складовими товароруху. На етапі стандартизації розроблено поетапну схему використання узагальнених типових стандартів, яка враховує особливості різних типів товарних ринків. Запропоновано інноваційний підхід до інституційного забезпечення регламентації використання стандартів товароруху в умовах нестабільного ринкового середовища, що передбачає фрормування універсальних логістичних ланцюгів товарних ринків із надання багатоваріантних послуг.

Ключові слова: інституційна складова, опис, стандартизація, регламентація, типовий режим товарного ринку.

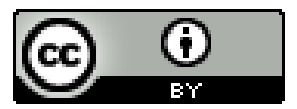

This work is licensed under a Creative Commons Attribution 4.0 International License http://creativecommons.org/licenses/by/4.0/
Постановка проблеми та її зв'язок з важливими науковими та практичними завданнями. Трансформаційні перетворення в системі товарних ринків, пов'язані зі значним скороченням масштабів торговельної діяльності (приблизно на одну третину), актуалізують завдання пошуку нових підходів до забезпечення ефективної діяльності суб'єктів ринку. В якості однієї зі складових теоретичного базису адаптації товароруху до нових умов доцільно розглянути механізм регламентації товарних постачань.

Основу регламентації складають інституційні інструменти та важелі впорядкування процесів (дій) у відносинах між елементами логістичної системи. У дослідженні авторами висунуто гіпотезу, відповідно до якої регламентація уявляє собою найбільш адекватний та дієвий механізм впливу на результативність товарних постачань, від ступеню упорядкованості та послідовності якої в визначальній мірі залежить в цілому результативність товароруху в ринкових ланцюгах. Провідний вплив регламентації на логістику товарного ринку пояснюється складною процедурою обслуговування товароруху, доповненою процесами щодо проміжного зберігання товару, його доробки, передпродажної сервісної підготовки, розподілу, постачань у торговельні мережі, кінцевої реалізації товару, при якій упорядкування відносин між переліченими складовими постачань створює суттєвий резерв підвищення результативності товароруху.

Додатково роль регламентації посилюється в масштабі товарних ринків як цілісних об'єктів відтворення товароруху. В складі товарних ринків функціонує множина логістичних ланцюгів, які мають різну структуру, обсяги, цілі обслуговування товарних потоків. В той же час вони об'єднані специфічними умовами товароруху, які визначаються параметрами ринків та їх типів: товарною спеціалізацією,

*Публікацію підготовлено в межах виконання НДР «Формування ефективної логістики товарних ринків» (№ державної реєстрації 0119U000227) 
географічними та товарними межами, ринковою конкуренцією тощо. У результаті створюються передумови для виокремлення узагальнених логістичних ланцюгів в якості самостійних об'єктів регламентації. Під узагальненим логістичним ланцңюгом будемо розуміти взаємопов'язану сукупність типових ланок, які об'єднують процес товароруху у єдину відтворювальну систему, притаманну товарному ринку, або певному його типу. За таких умов визначення регламентів товароруху в межах товарного ринку представляє собою вкрай актуальне завдання, орієнтоване на підвищення ефективності ринкової логістики.

Аналіз останніх публікацій по проблемі. Проблематика ефективного регулювання матеріальних потоків на основі теорії регламентації відображена в працях вітчизняних та іноземних учених, зокрема, Д. Бауерсокса [1], Є.В. Крикавського [2], М. Кристофера [3], К. Лайсонса [4], М.А. Окландера [5], Н.I. Чухрай [6]. Д. Уотерса та ін. Питання формування та регулювання логістичних ланцюгів товарних ринків знаходяться в центрі досліджень науковців Інституту проблем ринку та економіко-екологічних досліджень НАН України [7, 8, 9]. Незважаючи на певну розробленість даної проблематики, залишається невизначеною низка актуальних питань, пов'язаних із теоретико-методологічними аспектами імплементації інструментів регламентації до умов товароруху в складі товарних ринків. Зокрема, це стосується структуризації інституційної складової регламентації та врахування особливостей іiі впровадження в сучасних умовах ринкових трансформацій.

Мета статті. Мета статті - обгрунтування перспективних напрямів впровадження інституційної складової регламентації процесів товароруху в системі товарних ринків та розробка інструментів іiі адаптації до сучасних трендів логістичного обслуговування товарних постачань.

Виклад основних результатів та їх обгрунтування. В загальновизнаному контексті інституційну складову регламентації забезпечують інституційні інструменти та важелі упорядкування процесів у відносинах між елементами системи. В свою чергу, під упорядкуванням розуміється економічно та технологічно взаємозв'язаний та взаємообумовлений стан відносин між структурними елементами процесу, які задовольняють як загальним цілям системи, так i окремим її складовим.

Особливість масштабу товарного ринку полягає в тому, що певні ринки та їх типи, особливо стратегічні товарні ринки, є об'єктами державного регулювання товароруху. У цих обставинах в роботі запропоновано виокремлювати зовнішню та внутрішню складові інституційних впливів на процес регламентації товароруху (табл. 1).

Таблиця 1

Зовнішня та внутрішня складові інституційних впливів на умови регламентації товароруху в ринках*

\begin{tabular}{|c|c|c|c|}
\hline \multicolumn{2}{|c|}{ Зовнішнс середовище впливів } & \multicolumn{2}{|c|}{ Внутрішнс середовище впливів } \\
\hline $\begin{array}{c}\text { Елементи інститу- } \\
\text { ційної бази (масш- } \\
\text { таб товарного ри- } \\
\text { нку) }\end{array}$ & $\begin{array}{l}\text { Склад елементів } \\
\text { (інститутів) }\end{array}$ & $\begin{array}{c}\text { Елементи інституційної } \\
\text { бази товароруху (мас- } \\
\text { штаб типового логіс- } \\
\text { тичного ланцюга) }\end{array}$ & $\begin{array}{l}\text { Склад елементів } \\
\text { (інститутів) }\end{array}$ \\
\hline $\begin{array}{l}\text { 1. Нормативно- } \\
\text { правові документи }\end{array}$ & $\begin{array}{l}\text { Офіційні документи, при- } \\
\text { йняті уповноваженими на } \\
\text { це суб'єктами нормотворчо- } \\
\text { сті у визначеній Законом } \\
\text { формі та за встановленою } \\
\text { процедурою. }\end{array}$ & 1. Інструкції & $\begin{array}{l}\text { Офіційні документи, які } \\
\text { містять опис та спосіб упо- } \\
\text { рядкування відносин між } \\
\text { складовими логістичного } \\
\text { ланцюга товароруху в рин- } \\
\text { ках }\end{array}$ \\
\hline $\begin{array}{l}\text { 2. Розпорядні до- } \\
\text { кументи }\end{array}$ & $\begin{array}{l}\text { Офіційні документи, при- } \\
\text { йняті Кабінетом Міністрів } \\
\text { України, окремими мініс- } \\
\text { терствами, регіональними } \\
\text { та місцевими органами вла- } \\
\text { ди (постанови, розпоря- } \\
\text { дження, накази тощо) }\end{array}$ & 2. Договори & $\begin{array}{l}\text { Офіційні документи між } \\
\text { двома або більшою кількі- } \\
\text { стю учасників товароруху } \\
\text { (ланками ланцюгів) з ме- } \\
\text { тою упорядкування право- } \\
\text { вих відносин та юридич- } \\
\text { них зобов’язань щодо ви- } \\
\text { конання }\end{array}$ \\
\hline $\begin{array}{l}\text { 3. Установчі доку- } \\
\text { менти }\end{array}$ & $\begin{array}{l}\text { Офіційні документи, які } \\
\text { створюють організаційно- } \\
\text { правову основу для функці- } \\
\text { онування різних форм влас- } \\
\text { ності в ринку }\end{array}$ & 3. Положення & $\begin{array}{l}\text { Офіційні документи, які } \\
\text { визначають правовий ста- } \\
\text { тус, підпорядкованість, } \\
\text { структуру, задачі, функції } \\
\text { управління та інші аспекти } \\
\text { організації товароруху }\end{array}$ \\
\hline $\begin{array}{l}\text { 4. Документи стра- } \\
\text { тегічного характе- } \\
\text { ру }\end{array}$ & $\begin{array}{l}\text { Офіційні документи, } \\
\text { пов’язані з розробкою кон- } \\
\text { цепцій та стратегій розвит- } \\
\text { ку товарних ринків }\end{array}$ & $\begin{array}{l}\text { 4. Нормативно- } \\
\text { методичні документи }\end{array}$ & $\begin{array}{l}\text { Офіційні документи, що } \\
\text { визначають порядок та } \\
\text { норми використання логіс- } \\
\text { тичних функцій в процесі } \\
\text { товароруху }\end{array}$ \\
\hline
\end{tabular}


Продовження табл. 1

\begin{tabular}{|c|c|c|c|}
\hline \multicolumn{2}{|c|}{ Зовнішнс середовище впливів } & \multicolumn{2}{|c|}{ Внутрішнс середовище впливів } \\
\hline $\begin{array}{l}\text { 5. Документи про- } \\
\text { грамного характе- } \\
\text { ру }\end{array}$ & $\begin{array}{l}\text { Офіційні документи, } \\
\text { пов'язані з розробкою про- } \\
\text { грам розвитку товарних } \\
\text { ринків }\end{array}$ & 5. Правила & $\begin{array}{l}\text { Офіційні документи, які } \\
\text { встановлюють процедурні } \\
\text { норми та визначають поря- } \\
\text { док здійснення товароруху }\end{array}$ \\
\hline \multicolumn{2}{|c|}{$\begin{array}{l}\text { Базові елементи інститутів: } \\
\text {-цілі реалізації документів; } \\
\text {-завдання реалізації документів; } \\
\text {-очікувані результати від впровадження документів }\end{array}$} & \multicolumn{2}{|c|}{$\begin{array}{l}\text { Базові елементи інститутів: } \\
\text { - параметри послідовності, ритмічності, періодичнос- } \\
\text { ті товароруху; } \\
\text { - усунення міжланкових розбіжностей; } \\
\text { - уніфікація параметрів } 3 \text { обслуговування товарних } \\
\text { потоків. }\end{array}$} \\
\hline
\end{tabular}

* Авторська розробка

Зовнішня складова інституційних впливів визначає державну політику по відношенню до певних товарних ринків, або їх типів. До неї відносяться:

- нормативно-правові акти;

- розпорядні документи, прийняті Кабінетом Міністрів, окремими міністерствами, регіональними та місцевими органами влади;

- установчі документи;

- документи стратегічного характеру;

- документи програмного характеру.

В межах кожного 3 документів виокремлюються цілі, завдання, очікувані результати, які формують орієнтири для наступного впровадження регламентних дій.

Внутрішня складова інституційних впливів безпосередньо визначає області товароруху, в межах яких необхідно здійснювати регламентні дії. За змістом регламентні документи класифікуються на (див. табл. 1):

- інструкції;

- договори;

- положення;

- нормативно-методичні документи;

- правила.

Регламентація поєднує в єдину систему опис діючого процесу товароруху, його стандартизацію та завершальний етап - розробку регламенту. На практиці виникає завдання забезпечення взаємної спорідненості перелічених етапів регламентації з урахуванням особливостей товароруху в системі товарних ринків. У дослідженні запропоновано авторський підхід до виконання перелічених етапів.

Перший етап - eman опису - полягає у відображенні процесу в такому вигляді, в якому він існує в реальності. Авторська позиція полягає у використанні комплексного підходу, який буде відповідати складним економічним процесам, зокрема, процесам товароруху в ринку. Критерієм комплексного підходу має бути взаємозв'язаний опис об'єкта за різними параметрами, сукупність яких дозволяє всебічно оцінювати поточну ситуацію. Такий підхід, з одного боку, дає можливість селективно підходити до вибору областей дослідження наступного етапу - етапу стандартизації, коли будь-якій області стандартизації буде відповідати детальний опис існуючої ситуації. 3 іншого боку, комплексний опис буде сприяти стандартизації товароруху в масштабі товарного ринку, що відповідає об'єкту дослідження.

Провідними складовими комплексного опису виступає взаємозв'язок технологічного, економічного та організаційного рівнів відносин між ланками логістичних ланцюгів товарних ринків. Фрагмент комплексного опису, спрямованого на визначення рівнів збалансованості міжланкових відносин, представлено у табл. 2.

Стандартизація прочесу товароруху - наступний етап регламентації, мета якого полягає у визначенні еталону, яким необхідно керуватись в процесі логістичного обслуговування товароруху. Запропоноване положення щодо охоплення стандартизацією узагальненого ланцюга товароруху в межах ринку ускладнює дану процедуру.

Таблиця 2

Складові комплексного опису ринкового товароруху*

\begin{tabular}{|l|l|}
\hline $\begin{array}{c}\text { Складові } \\
\text { комплексного опису }\end{array}$ & \multicolumn{1}{c|}{ Головні елементи опису } \\
\hline 1.Технологічний опис & $\begin{array}{l}\text { Аналіз технологічної взаємопов’язності міжланкових відносин в процесі перемі- } \\
\text { щення товарних потоків по логістичному ланцюгу ринку }\end{array}$ \\
\hline & $\begin{array}{l}\text { 1. Аналіз економічних передумов, організаційних форм та інструментів балансу- } \\
\text { вання міжланкових відносин. } \\
\text { 2. Оцінка відповідності функцій ланок цільовим орієнтирам ринкового ланцюга } \\
\text { (оптимізації ланцюгової доданої вартості, мінімізація ланцюгових логістичних } \\
\text { 2. Економічний опис } \\
\text { витрат та ін.) } \\
\text { 3.Опис впливів зовнішніх факторів на існуючу структуру та параметри міжланко- } \\
\text { вих відносин, зокрема: транспортного фактору, товарного імпорту, споживчого } \\
\text { фактору, екологічних обмежень та ін. }\end{array}$ \\
\hline
\end{tabular}


Продовження табл. 2

\begin{tabular}{|c|c|}
\hline $\begin{array}{c}\text { Складові } \\
\text { комплексного опису }\end{array}$ & Головні елементи опису \\
\hline $\begin{array}{l}\text { 3. Організаційний } \\
\text { опис }\end{array}$ & $\begin{array}{l}\text { 1. Варіант посередницького каналу, акцентується увага: } \\
\text { а) у випадку інтенсивного товароруху: на наявність товарних запасів для роздріб- } \\
\text { них мереж; } \\
\text { б) у випадку ексклюзивного продажу товарів: на рівень обмеження посередників } \\
\text { та їх виняткових прав на продаж товарів; } \\
\text { в) у випадку вибіркового (селективного) продажу товарів: на використання об- } \\
\text { меженої кількості оптових та роздрібних посредників, що дає можливість забез- } \\
\text { печувати високу рентабельність збуту товарів, що користуються найбільшим по- } \\
\text { питом. } \\
\text { 2. Варіант опису договірних відносин на засадах аутсорсингу: } \\
\text { а) співвідношення ланок, які функціонують в режимі аутсорсингу, та решти ла- } \\
\text { нок; } \\
\text { б) тривалість угод між замовником та аутсорсером; } \\
\text { в) вплив договірних відносин на стабілізацію параметрів товароруху; } \\
\text { г) рівень координації заходів між аутсорсером та замовником на предмет відпові- } \\
\text { дності якості та результативності виконання логістичних операцій. }\end{array}$ \\
\hline
\end{tabular}

* Авторська розробка

Одна з головних складностей полягає в тому, що масштаб ринку вимагає обгрунтування заходів в межах узагальненого ланцюга, обумовлюючи необхідність визначення узагальненого критерію (еталону), який буде відповідати даній умові. Для вирішення означеної проблеми в дослідженні пропонується використати методологічний підхід, який базується на принципі досягнення узагальнених типових стандартів товароруху (далі - УТС). Під УТС будемо розуміти сукупність типових стандартів, ідентифікованих в якості еталонів упорядкування товарних потоків в системі відповідних типів ринків. У такому варіанті стандартизація товарних потоків значно спрощується, оскільки вона буде зорієнтована не на окремі міжланкові відносини, а на всю узагальнену структуру товароруху, яка підпорядкована тому чи іншому типу товарних ринків.

3 метою впровадження УТС пропонується використання методології типових логістичних режимів (далі - ТЛР) [12] - взаємопов'язаних типових характеристик товароруху, які одночасно виступають у якості цільових орієнтирів відповідності типам товарних ринків. До ознак типових характеристик відносяться: а) стабільний характер проявів; б) відповідність цільових орієнтирів економічним умовам функціонування; в) уявлення в якості складових теорії ринків. Перераховані ознаки надають підстави для висування гіпотези, згідно з якою типові характеристики можна прирівняти до типових стандартів товароруху. Дане гіпотетичне твердження має певний набір об'єктивних передумов для його наступного теоретичного обгрунтування.

По-перше, в складі переважної більшості регламентів, наприклад, посадових регламентів, регламентів окремих видів логістичної діяльності (складська логістика, логістика оптової та роздрібної торгівлі тощо $[13,14])$, їх структура безпосередньо не залежить від особливостей товарних ринків. У нашому випадку стандарти «поведінки» міжланкових відносин визначаються типовими характеристиками ринку та виступають у якості цільових орієнтирів (еталонів) стандартизації товароруху.

По-друге, типові характеристики товароруху задають цільові орієнтири стандартизації міжланкових відносин, оскільки відповідають економічно визначеним параметрам функціонування логістичних ланцюгів. Стійкий характер проявів типових характеристик тільки підтверджує економічну доцільність їх використання.

По-третє, типові характеристики товароруху створюють складову теорії ринків, що доведено всебічним та багаторазовим дослідженням умов їх проявів, результати якого формують підгрунтя для їх інтерпретації на рівні узагальнених закономірностей.

Проведення етапу стандартизації пропонується здійснювати в наступній послідовності дій:

- визначення УТС товароруху у відповідності з типом товарних ринків;

- групування типових стандартів за цільовими орієнтирами типових характеристик товарору$\mathrm{xy}$

- співставлення типових стандартів 3 реальними умовами логістичного обслуговування товарних потоків, виділення проблемних типових стандартів, яким не відповідають існуючі умови логістичного обслуговування товароруху;

- впровадження інституційних важелів 3 досягнення типових стандартів товароруху.

Як приклад, нами була досліджена низка узагальнених типових стандартів товароруху в складі окремих типів товарних ринків: просторових УТС (локальний, регіональний, національний тип ринків) та УТС в складі типу потенційних ринків (ринкових ніш). Послідовна схема стандартизації процесу товароруху у розрізі типів ринків наведена в табл. 3 . 
Послідовна схема стандартизації процесу товароруху в складі типів товарних ринків*

\begin{tabular}{|c|c|c|c|}
\hline $\begin{array}{l}\text { Тип товарного } \\
\text { ринку, УТС }\end{array}$ & $\begin{array}{l}\text { Цільові оріснтири типових стандар- } \\
\text { тів товароруху }\end{array}$ & $\begin{array}{l}\text { Проблемні типові } \\
\text { стандарти товароруху } \\
\text { та їх зміст }\end{array}$ & $\begin{array}{l}\text { Інститути зовніш- } \\
\text { ньої складової } \\
\text { впливів на усунен- } \\
\text { ня проблемних } \\
\text { ситуацій }\end{array}$ \\
\hline $\begin{array}{l}\text { 1. Ринки лока- } \\
\text { льного рівня, } \\
\text { УТС локально- } \\
\text { го рівня }\end{array}$ & $\begin{array}{l}\text { 1.Завершені ланцюги з виробництва та } \\
\text { реалізації товарів, економічні, споживчі } \\
\text { та інші умови функціонування яких } \\
\text { обмежені географічними кордонами } \\
\text { локальної території. } \\
\text { 2. Відповідність обсягів, термінів, пері- } \\
\text { одичності обслуговування товарних } \\
\text { постачань вимогам місцевого попиту. } \\
\text { 3. Доступність товарних постачань кін- } \\
\text { цевим покупцям. }\end{array}$ & $\begin{array}{l}\text { Відсутність певних } \\
\text { ланок ланцюгів з виро- } \\
\text { бництва та збуту това- } \\
\text { рів }\end{array}$ & $\begin{array}{l}\text { Місцеві гарантії ін- } \\
\text { весторам, місцеві } \\
\text { програми підтримки } \\
\text { малого та середнього } \\
\text { підприємництва }\end{array}$ \\
\hline $\begin{array}{l}\text { 2. Ринки регіо- } \\
\text { нального рівня, } \\
\text { УТС регіональ- } \\
\text { ного рівня }\end{array}$ & $\begin{array}{l}\text { 1. Логістичні ланцюги з обслуговування } \\
\text { міжрегіонального товарообміну } \\
\text { 2. Збалансованість ланок збуту товарів } 3 \\
\text { постачальницькими (сировинними) } \\
\text { ланками периферійних районів. }\end{array}$ & $\begin{array}{l}\text { Розбалансованість па- } \\
\text { раметрів споживчої } \\
\text { ланки з параметрами } \\
\text { ланки товарних поста- } \\
\text { чань із периферійних } \\
\text { сировинних зон }\end{array}$ & $\begin{array}{l}\text { Розробка та впрова- } \\
\text { дження регіональ- } \\
\text { них проектів розви- } \\
\text { тку міжтермінальної } \\
\text { організації товаро- } \\
\text { руху. }\end{array}$ \\
\hline $\begin{array}{l}\text { 3. Ринки націо- } \\
\text { нального рівня, } \\
\text { УТС націона- } \\
\text { льного рівня }\end{array}$ & $\begin{array}{l}\text { 1. Логістичні ланцюги з обслуговування } \\
\text { зовнішньоекономічних зв’язків; } \\
\text { 2.Взаємопов’язане та взаємообумовлене } \\
\text { функціонування логістичних ланцюгів } \\
\text { товароруху національного рівня з логіс- } \\
\text { тичними ланцюгами регіонального та } \\
\text { локального рівнів. }\end{array}$ & $\begin{array}{l}\text { Відсутність логістич- } \\
\text { них перехресть із } \\
\text { централізованого пла- } \\
\text { нування та комплекс- } \\
\text { ного обслуговування } \\
\text { товарних потоків, взає- } \\
\text { мозв'язаних між собою } \\
\text { ієрархічно упорядкова- } \\
\text { ними просторовими } \\
\text { рівнями }\end{array}$ & $\begin{array}{l}\text { Розробка та впрова- } \\
\text { дження загальнона- } \\
\text { ціональної програ- } \\
\text { ми формування ме- } \\
\text { реж логістичних } \\
\text { перехресть, ієрархі- } \\
\text { чно взаємозв'язаних } \\
\text { між собою націона- } \\
\text { льним, регіональ- } \\
\text { ним та локальним } \\
\text { рівнями обслугову- } \\
\text { вання товарних по- } \\
\text { токів. }\end{array}$ \\
\hline $\begin{array}{l}\text { 4. Потенційні } \\
\text { ринки } \\
\text { (ринкові ніші), } \\
\text { УТС ринкових } \\
\text { ніш }\end{array}$ & $\begin{array}{l}\text { 1.Логістичні ланцюги з обслуговування } \\
\text { повного життєвого циклу товару. } \\
\text { 2. Визначальний вплив логістичних ла- } \\
\text { нцюгів на результативність освоєння } \\
\text { ринкових ніш. }\end{array}$ & $\begin{array}{l}\text { Визначальний вплив } \\
\text { логістичних ланцюгів } \\
\text { на результативність } \\
\text { освоєння ринкових } \\
\text { ніш. } \\
\text { Проблема забезпечення } \\
\text { пріоритетного впливу } \\
\text { логістичних ланцюгів } \\
\text { на освоєння ринкових } \\
\text { ніш. }\end{array}$ & $\begin{array}{l}\text { Державна підтримка } \\
\text { залучення крупних } \\
\text { логістичних про- } \\
\text { вайдерів з централі- } \\
\text { зованого освоєння } \\
\text { ринкових ніш шля- } \\
\text { хом створення на } \\
\text { засадах державно- } \\
\text { приватного парт- } \\
\text { нерства мереж логі- } \\
\text { стичних каналів } 3 \\
\text { охопленням всіх } \\
\text { провідних центрів } \\
\text { споживання товару. }\end{array}$ \\
\hline
\end{tabular}

* Авторська розробка

Використання стандартів товароруху - це завершальний етап процесу регламентації. Даний етап полягає у впровадженні регламентних документів, які мають визначати умови використання стандартів товароруху.

В сучасних умовах економічної турбулентності інституційна складова регламентації товароруху знаходиться під впливом ринкових змін. Цей процес посилюється складною структурою товароруху, в межах якої учасники формують нові конфігурації товарних потоків. Відповідно, потребує певного уточнення методологія використання типових стандартів, пов'язаних із реагуванням на зміни у товарорусі. В першу чергу, це стосується впливів 
нестабільного зовнішнього середовища. Під нестабільним зовнішнім середовищем будемо розуміти фактори, які діють за межами процесу товароруху, впливають на нього переважно в негативному аспекті та зосереджуються в областях змін географічних і товарних меж ринків, коливань обсягів та номенклатури постачань, мінливостей ринкової кон'юнктури тощо.

Авторська позиція полягає в тому, що в нестабільному ринковому середовищі областю використання типових стандартів мають розглядатись змінні показники товароруху: товарна номенклатура, іiі обсяги, географія постачань і таке інше. В той же час зазначимо, що перелічені змінні показники не відповідають провідному принципу - принципу стабільності використання стандартів. Термін дії стандартів у такій ситуації буде завершатись 3 початком змін у показниках товароруху, по відношенню до яких буде потрібно розробляти наступні типові правила використання стандартів.

У зв'язку з цим у дослідженні пропонується інноваційний підхід, який передбачає розробку та впровадження інституційних важелів трансформації типових стандартів у гнучкі (універсальні) типові стандарти. Під гнучким типовим стандартом будемо розуміти типовий стандарт узагальненого ланцюга товароруху, адаптований під нестабільне ринкове середовище.

Перетворення типових стандартів у гнучкі (універсальні) типові стандарти передбачає відбір базових ланок, технологічні умови використання яких формують основу для наступного перетворення логістичних ланцюгів в універсальні (багатоваріантні) системи для забезпечення кумулятивного ефекту «гнучкості» товароруху. Дана методологія передбачає послідовне виконання наступних дій (табл. 4):

- визначення ознак виокремлення змінних параметрів з обслуговування товарних постачань;

- відбір базових ланок логістичних ланцюгів, за якими доцільно надавати універсальні багатоваріантні послуги. Під багатоваріантністю будемо розуміти різноманіття варіантів надання логістичних послуг, які потребують відповідного різноманіття умов їх виконання;

- упорядкування відносин між гнучкими (універсальними) ланками логістичних ланцюгів.

Таблиця 4

Етапи перетворення типових стандартів в універсальні типові стандарти товароруху в системі товарних ринків*

\begin{tabular}{|c|c|}
\hline Етапи & Змістовна сутність етапу \\
\hline $\begin{array}{l}\text { 1. Визначення ознак вио- } \\
\text { кремлення змінних пара- } \\
\text { метрів } 3 \text { обслуговування } \\
\text { товарних постачань }\end{array}$ & $\begin{array}{l}\text { Технологічна можливість надання логістичних послуг суб'єктами ринкового } \\
\text { ланцюга за різними параметрами: часовими, температурними, обсягами, пе- } \\
\text { ріодичністю постачань тощо. }\end{array}$ \\
\hline $\begin{array}{l}\text { 2. Регламентні документи } \\
3 \text { надання гнучких (бага- } \\
\text { товаріантних) послуг }\end{array}$ & $\begin{array}{l}\text { 1. Ланка обслуговування збірних товарних партій: } \\
\text { а) впровадження регламентних документів щодо упорядкування функціону- } \\
\text { вання консолідаційного складу (розробка положення щодо функціонування } \\
\text { консолідаційного складу; розробка інструкцій, які повинні містити опис та } \\
\text { спосіб упорядкування взаємопов'язаної низки процесів із консолідації това- } \\
\text { рних партій); } \\
\text { б) зв’язок ланки консолідацї̈ товарних партій в збірні партії з ланкою розук- } \\
\text { рупнення збірних партій та їх відвантаження споживачам (договірні відно- } \\
\text { сини, упорядкування юридичних зобов'язань кожної зі сторін; розробка но- } \\
\text { рмативно-методичних документів, які визначають порядок, правила та нор- } \\
\text { ми міжланкових відносин щодо взаємообумовленого використання збірних } \\
\text { товарних партій). } \\
\text { 2.Ланка використання модульних технологій: } \\
\text { а) правила визначення порядку розробки проєктної документації на викори- } \\
\text { стання технологічного та допоміжного обладнання, які забезпечують узго- } \\
\text { джене (синхронне) функціонування модульних потужностей в складі взає- } \\
\text { мопов’язаних ланок ринкових ланцюгів; } \\
\text { б) інструкції щодо визначення порядку синхронного виконання комплексу } \\
\text { робіт, пов’язаних із вводом в експлуатацію модульних потужностей; } \\
\text { в) нормативно-методичні документи щодо визначення порядку логістичної } \\
\text { оптимізації використання модульних потужностей в умовах переорієнтації } \\
\text { на нові ринки збуту, передислокації в інші пункти локалізації тощо. }\end{array}$ \\
\hline $\begin{array}{l}\text { 3. Упорядкування відно- } \\
\text { син між гнучкими (універ- } \\
\text { сальними) ланками логіс- } \\
\text { тичних ланцюгів }\end{array}$ & $\begin{array}{l}\text { Впровадження інструментів наскрізного планування міжланкової взаємодії у } \\
\text { відповідності до умов нестабільного зовнішнього середовища }\end{array}$ \\
\hline
\end{tabular}


Продовження табл. 4

\begin{tabular}{|c|c|}
\hline Етапи & Змістовна сутність етапу \\
\hline $\begin{array}{l}\text { 3.1. Визначення меж на- } \\
\text { скрізного планування } \\
\text { відносин між гнучкими } \\
\text { (універсальними) ланка- } \\
\text { ми логістичних ланцюгів }\end{array}$ & $\begin{array}{l}\text { Критерій визначення ланки надання універсальних багатоваріантних послуг: } \\
\text { наявність економічних умов для періодичних змін параметрів товарних по- } \\
\text { токів: їх укрупнення (розукрупнення), об’єднання, злиття, поглинання та ін., } \\
\text { що залежить від змін споживчого попиту. }\end{array}$ \\
\hline $\begin{array}{l}\text { 3.2. Визначення умов на- } \\
\text { скрізного планування } \\
\text { відносин між гнучкими } \\
\text { (універсальними) ланка- } \\
\text { ми логістичних ланцюгів }\end{array}$ & $\begin{array}{l}\text { Розробка нормативно - методичних документів щодо оптимізації міжланко- } \\
\text { вої взаємодії (в основу розробки нормативно-методичних документів пропо- } \\
\text { нується покласти принцип «норми відхилень», який має враховувати низку } \\
\text { факторів, що створюють різницю в обсягах товарних потоків між виробн- } \\
\text { чою та споживчою (торговельною) ланкою). Послідовність розрахунків має } \\
\text { включати: } \\
\text { а) порядок планування асортименту та кількості товару, який повинен бути } \\
\text { поставлений у роздрібні мережі у відповідності } 3 \text { плановими заявками ме- } \\
\text { реж; } \\
\text { б) порядок визначення та повернення частини асортименту товаровиробни- } \\
\text { ку з причин невідповідності договірним зобов'язанням з роздрібними мере- } \\
\text { жами; } \\
\text { в) порядок планування асортименту та кількості товару, який повинен бути } \\
\text { доставлений в роздрібні мережі в умовах ситуативної зміни попиту. }\end{array}$ \\
\hline $\begin{array}{l}\text { 3.3. Визначення рівнів } \\
\text { наскрізного планування } \\
\text { відносин між гнучкими } \\
\text { (універсальними) ланка- } \\
\text { ми логістичних ланцюгів }\end{array}$ & $\begin{array}{l}\text { Рівень наскрізного планування: логістична операція. } \\
\text { Варіант регламентації наскрізного планування: } \\
\text { а) товарні поставки від розподільчої ланки до роздрібних мереж; } \\
\text { б) товарні поставки від товаровиробників до розподільчої ланки. }\end{array}$ \\
\hline
\end{tabular}

* Авторська розробка

У складі типових стандартів товароруху слід розрізняти постійні та змінні параметри. Постійним параметрам відповідають нормативи запровадження логістичних операцій незалежно від динаміки показників товарних постачань: обсягів, періодичності тощо. Наприклад, в складі типових стандартів з обслуговування швидкопсувних товарів (молочні, хлібобулочні вироби тощо) до постійних відносять часові та температурні нормативи товарних постачань. Невідповідність нормативам призводить до передчасного псування продукції [15]. Ознакою змінних параметpis є технологічна можливість надання логістичних послуг за різними варіантами обсягів, періодичності, термінів постачань тощо. Змінні параметри тісно залежать від динаміки змін споживчого попиту.

Ланки ринкових логістичних ланцюгів, які спроможні надавати універсальні (багатоваріантні) послуги, формують кумулятивний ефект «гнучкості» стандартів товароруху. За даними експертів, в результаті надання універсальних (багатоваріантних) послуг обсяги виконання замовлень збільшуються на 20$40 \%$, а рівень їх задоволення - на $30 \%$ [6]. У дослідженні визначено дві ланки, яким відповідають вище перелічені умови: (1) ланка обслуговування збірних товарних партій; (2) ланка використання модульних технологій.

Регламентаиія обслуговування збірних товарних партій має включати дві групи регламентних документів. Перша група передбачає впорядкування функціонування консолідаційного складу - центрального об'єкту формування збірних товарних партій [16]. Даний процес передбачає:
- розробку та впровадження положення щодо функціонування консолідаційного складу, в якому визначені правовий статус об'єкта логістичної діяльності, його місце в структурі логістичного ланцюга, задачі, функції, які він має виконувати в якості складової гнучкого (універсального) типового стандарту товароруху;

- перелік інструкцій, що повинні містити опис та спосіб упорядкування взаємозв'язаної низки технологічних заходів 3 використання консолідаційного складу: (1) інструкцію 3 прийому та розміщення товарних партій різних постачальників; (2) інструкцію з визначення порядку консолідації товарних партій різних постачальників у збірні товарні партії; (3) інструкцію щодо визначення порядку розукрупнення збірних товарних партій та їх відвантаження споживачам.

Друга група регламентних документів забезпечує зв'язок консолідаційної ланки з відповідною ланкою розукрупнення товарних партій. У цьому контексті використовуються:

- договірні відносини зі співучасниками обслуговування збірних товарних партій шляхом упорядкування правових відносин та юридичних зобов’язань між відповідними ланками ланцюга;

- нормативно-методичні документи, які визначають порядок, правила та норми міжланкових відносин із взаємообумовленого обслуговування збірних товарних партій: часові регламенти, регламенти щодо балансування обсягів збірних товарних партій iн. 
Особливість регламентації модульної технології обслуговування товароруху полягає в тому, що у багатоваріантному обслуговуванні товарних потоків зміни модульних потужностей мають здійснюватись синхронно у взаємопов'язаній системі виробничих, складських та розподільчих модулів. Тому основною вимогою до регламентних документів постає узгоджена між учасниками товароруху зміна параметрів модулів та їх подальшого взаємообумовленого використання. Регламентні документи включають:

- правила визначення порядку узгодження розробки проектної документації на використання технологічного та допоміжного обладнання в складі взаємозв'язаних ланок ланцюгів;

- інструкції щодо визначення порядку узгодження виконанням комплексу робіт, пов'язаних із вводом в експлуатацію модульних потужностей;

- нормативно-методичні документи щодо визначення порядку узгодження оптимізації використання модульних потужностей в умовах переорієнтації на нові ринки збуту.

Таким чином, нами пропонується розширене запровадження селективного підходу до використання типових стандартів товароруху шляхом визначення вузлових ланок надання гнучких послуг з наступним розповсюдженням надання універсальних послуг на решту ланок ринкових ланцюгів.

Упорядкування відносин між гнучкими (універсальними) ланками ланцюгів передбачає запровадження інструментів наскрізного планування міжланкової взаємодії у відповідності з умовами нестабільного зовнішнього середовища. Регламентація наскрізного планування потребує визначення декількох питань, від яких залежить змістовна складова регламентації. Зокрема, потребують конкретизації межі, умови та рівні планування.

Межі наскрізного планування визначаються базовими універсальними ланками, які формують загальний логістичний простір з надання багатоваріантних послуг. Базовою ланкою у нашому дослідженні будемо розглядати розподільчу ланку, змінні параметри якої залежать від змін заяв роздрібних мереж на товарні постачання (роздрібні мережі не розглядаються в якості кінцевих ланок, оскільки вони не передбачають використання багатоваріантного підходу: різні обсяги заяв на товар здійснюються в межах існуючих площ роздрібних мереж).

Умови наскрізного планування мають відображатись у нормативно - методичних документах щодо оптимізації міжланкової взаємодії. В основу розробки нормативно-методичних документів пропонується покласти «норму відхилень» - низку факторів, які створюють різницю в обсягах товарних потоків між виробничою ланкою та ланкою роздрібної торгівлі. Регламентація норми відхилення передбачає наступну послідовність дій:

- порядок планування асортименту та кількості товару, який повинен бути поставлений у роздрібні мережі у відповідності з плановими заявками мереж;

- порядок визначення та повернення части- ни асортименту товаровиробнику з причин невідповідності договірним зобов'язанням з роздрібними мережами (пересортування, довільні зміни цін ін.);

- порядок планування асортименту та кількості товару, який повинен бути доставлений в роздрібні мережі в ситуації зміни попиту.

Кожна $з$ регламентних дій потребує певного узгодження з попередніми діями та коригування планових обсягів товароруху.

Наскрізне планування передбачає уточнення рівнів запровадження регламентних заходів. У цьому контексті слід звернути увагу на рівень ланок ланцюгів та рівень логістичних операцій. Відповідно до загальноприйнятого уявлення, ланка - це складова логістичного ланцюга, функціонально відокремлена від інших ланок, яка виконує локальне завдання в системі товароруху продукції: постачання, складування, розподіл тощо. Дане трактування дещо розмиває визначення об'єкта наскрізного планування, оскільки ланка не уточнює області наскрізної взаємодії міжланкових зв'язків. Це обумовлено тим, що кожна ланка об'єднує певну кількість логістичних операцій - завершених дій, які не спроможні до подальшого розукрупнення. Тобто рівень логістичних операцій $є$ більш предметним. Наприклад, ланка товарних постачань включає такі логістичні операції, як завантаження, перевезення, розвантаження товару; ланка 3 доробки товару представлена логістичними операціями з сортування, ремонту, комплектації, упаковки товару.

Один 3 варіантів передбачає використання наскрізної логістичної операції з планування товарних потоків: (1) від розподільчої ланки до роздрібних мереж; (2) від товаровиробників до розподільчої ланки.

В першому випадку розробляються інструкції щодо виконання заяв роздрібних мереж. Переваги такого підходу полягають у можливості планування поставок за фактичними обсягами продаж, усунувши зайві обсяги товарів в роздрібних мережах. В другому випадку інструкції мають передбачати: (1) визначення оптимальних коридорів планування обсягів постачань товарів до розподільчої ланки; (2) визначення аналогічних оптимальних коридорів 3 планування термінів постачань товарів до розподільчої ланки [17].

Результативність наскрізного планування залежить від наявності суб'єкта планування, який спроможний контролювати наскрізний процес та відповідати за його кінцевий результат. До таких суб'єктів планування можна віднести сучасні організаційно-правові форми товароруху: корпоративну логістику, інтеграційні об'єднання, логістичні кооперативи, логістичні провайдери тощо.

Висновки та перспективи подальших досліджень. Регламентація представляє собою провідний чинник впливу на результативність товароруху в ринкових системах. Це обумовлено складною процедурою обслуговування товароруху, доповненою міжланковою взаємодією. Упорядкування цього процесу створює резерви зростання ефективності товарних 
постачань, що потребує всебічного врахування особливостей товароруху в системі товарних ринків на етапах опису, стандартизації та регламентації використання стандартів товароруху.

У дослідженні на етапі опису запропоновано застосування взаємопов'язаного опису технологічної, економічної та організаційної складової відносин між учасниками товароруху, що надає можливість використовувати як селективний, так і повний варіант стандартизації товароруху в межах ринкових ланцюгів. Переваги методологічного підходу до стандартизації товароруху на основі характеристик типів товарних ринків полягають у використанні економічно обгрунтованих рішень стандартизації, які визначаються цільовими орієнтирами характеристик ринків; формуванні стійкого характеру проявів стандартів; представлення стандартів у якості складової теорії товарних ринків, як наукового підгрунтя для встановлення сучасних закономірностей ринкового товароpyxy.

У ході дослідження визначено головні особливості формування інституційного базису регламентації товароруху в системі товарних ринків, а саме: (1) пріоритетне використання централізованих форм регламентації товароруху; (2) узгодження між головними учасниками товароруху загальних цілей регламентації міжланкових відносин у відповідності до типових характеристик товарних ринків; (3) забезпечення спільної мотивації учасників логістичних процесів до адаптації типових стандартів товароруху у відповідності з типовими характеристи- ками ринків. Результативність перелічених заходів залежить від наявності суб'єктів, спроможних контролювати наскрізний процес регламентації та відповідати за його кінцевий результат. До таких суб'єктів планування можна віднести сучасні організаційноправові форми товароруху в ринках: корпоративну та кооперативну логістику, логістичні провайдери тощо.

Наукова новизна проведеного дослідження полягає в розробці концептуальних основ формування інституційного базису регламентації товароруху в системі товарних ринків. Практичне значення отриманих результатів полягає у використанні розробленого теоретичного базису регламентації в якості наукового підгрунтя для розробки регламентів окремих товарних потоків з урахуванням особливостей типів товарних ринків. Запропонований авторами інноваційний підхід щодо трансформації типових стандартів у гнучкі (універсальні) типові стандарти товароруху надає можливість оптимізувати процес використання стандартів на засадах наскрізного планування міжланкових зв'язків у відповідності з умовами нестабільного ринкового середовища, може бути використаним суб'єктами управління для оптимізації логістичних процесів у ринкових ланцюгах.

Впровадження розроблених авторами теоретичного базису регламентації та методичного підходу до трансформації ринкових ланцюгів в умовах нестабільного середовища у практичну діяльність учасників потокових процесів певних товарних ринків формує перспективи подальших досліджень у даному науково-прикладному напрямі.

\section{Література}

1. Bowersox D.J. Lessons learned from the world class leaders. Supply Chain Management Review. 1997. Vol. 1. № 1. P.61-67.

2. Крикавський Є.В. Логістика. Для економістів. Львів: Видавництво Національного університету «Львівська політехніка», 2004. 448 с.

3. Christopher M.L. Logistics and supply chain management. London: Financial Times Prentice Hall, 1998.

4. Лайсонс К., Джиллингем М. Управление закупочной деятельностью и цепью поставок: монография. М.: ИНФРА-М, 2005. 798 с.

5. Окландер М.А. Логістика. К.: Центр учбової літератури, 2008. 346 с.

6. Чухрай Н.І. Оцінювання функціонування ланцюга поставок: сутність та концептуальні підходи. Львів. НУ «Львівська політехніка», 2009. URL: http://ena.lp.edu.ua:8080/bitstream/ntb/2754/1/48.pdf (дата 3вернення: 5.07.2021)

7. Буркинський Б.В., Нікішина О.В., Тараканов М.Л. та ін. Організаційно-економічні механізми формування ефективної логістики товарних ринків: монографія / за ред. Б. В. Буркинського, О.В. Нікішиної. Одеса: ІПРЕЕД НАН України, 2021. 261 с.

8. Буркинський Б.В., Нікішина О.В. Теоретико-методичний підхід до взаємодії економічних інтересів суб’єктів логістичних ланцюгів товарних ринків: наук. доповідь. Одеса: ІПРЕЕД НАН України, 2020. 63 с.

9. Nikishyna Oksana, Lozova Tetiana. Stimulating the development of cooperative logistics of the agri-food market of Ukraine in the conditions of digitalization. Selected aspects of digital society development: monograph. Publishing House of University of Technology, Katowice, 2021. P.226-236. URL: http://www.wydawnictwo.wst.pl/uploads/files/fd7b8107149ebd5a161d53e43d7ddb2d.pdf (дата звернення: 5.07.2021)

10. Норт Д. Институты, институциональные изменения и функционирование экономики; пер. с англ. А.Н. Нестеренко. М.: Начала, 1997. 190c. URL: http://cee-moscow.com/doc/izd/North.pdf (дата звернення: 5.07.2021)

11. Картавенко С.H. Описание и регламентация бизнес-процессов. URL: https://www.cfin.ru/itm/bpr/key_realize.shtml/ (дата звернення: 5.07.2021) 
12. Тараканов Н.Л. Региональные логистические системы: проблемы формирования и развития: монография. Одесса: ИПРЭЭИ Украины, 2013. 312 с.

13. Управління складом. Скорочення витрат у складській логістиці: веб-сайт. URL: https://www.tot.com.ua/warehouse-management/ (дата звернення: 7.07.2021)

14. Управління закупівлями. URL: https://stud.com.ua/14279/logistika/upravlinnya_zakupivlyami (дата звернення: 7.07.2021)

15. Перевезення швидкопсувних вантажів: правила i умови зберігання: веб-сайт. URL: https://www.cargo-ukraine.com/uk/perevezennya-shvidkopsuvnix-vantazhiv/ (дата звернення: 7.07.2021)

16. Реалії ринку збірних перевезень: веб-сайт. URL: https://euroshuttle.com.ua/blog/realii-rynka-sbornykhperevozok-ua/ (дата звернення: 7.07.2021)

17. Тараканов М.Л., Маковеєв А.П. Логістичний фактор формування доданої вартості в системі товарних ринків // Економіка: реалії часу. 2015. № 2. С 125-130.

Стаття надійшла 20.07.2021

Стаття прийнята до друку 3.08.2021

Доступно в мережі Internet 24.10.2021

Nikishyna 0.

Doctor of Economics, Senior Researcher Head of Department of Market Mechanisms and Structures

E-mail: ksenkych@gmail.com ORCID ID: 0000-0002-7172-3551

\section{Tarakanov $\mathbf{M}$}

PhD in Economics, Senior Researcher

Department of market mechanisms and structures

E-mail: tarakanovnikolajleonidovic@gmail.com ORCID ID: 0000-0002-3827-2373

\section{Zerkina 0.}

PhD in Economics, Associate Professor, Applicant of Department of market mechanisms and structures Institute of Market Problems and Economic \& Ecological Research of National Academy of Sciences of Ukraine Frantsuzskiy boulevard, 29, Odesa, Ukraine, 65044 E-mail: oksana27@i.ua ORCID ID: 0000-0002-2500-3959

\section{THE INSTITUTIONAL COMPONENT OF THE REGULATION OF COMMODITY CIRCULATION IN THE SYSTEM OF COMMODITY MARKETS}

The article is devoted to the development of the theoretical foundations for the formation of an institutional basis for the regulation of the process of commodity circulation in the system of commodity markets. The external and internal components of the institutional impact on the regulation of commodity circulation in the market have been highlighted. The conceptual approach to the regulation of commodity circulation at the stage of its description, achievement of commodity circulation standards, determination of options for using commodity circulation standards has been substantiated.

At the stage of description, an integrated approach has been proposed with the combination of technological, economic and organizational types of relations between the constituent elements of commodity circulation.

At the stage of standardization, a step-by-step scheme for the use of generalized uniform standards was developed, which takes into account the peculiarities of different types of markets. In this case, the sequence of actions includes: (1) defining a generalized uniform standard in accordance with the type of product market; (2) grouping of uniform standards according to targets of typical characteristics of commodity circulation; (3) comparison of uniform standards with the real conditions of the logistics service of commodity flows; (4) highlighting of problematic uniform standards that are not met by the current conditions of logistics services for goods movement; (5) development and use of institutional instruments for the implementation of uniform standards of commodity circulation.

An innovative approach to institutional support for the regulation of commodity circulation standards in an unstable market environment has been proposed. An algorithm for the formation of universal supply chains for the provision of multivariate services has been developed. This algorithm assumes the sequential execution of the following actions: (1) determination of signs of variable parameters for servicing 
commodity deliveries; (2) selection of basic links in supply chains for the provision of universal services; (3) streamlining the relationship between the universal links in supply chains.

The scientific novelty of the research consists in the development of conceptual foundations for the formation of an institutional basis for the regulation of commodity circulation in the system of commodity markets. The practical significance of the results obtained lies in the use of the theoretical basis of regulation as a scientific basis for the development of regulations for individual commodity flows, taking into account the characteristics of the types of commodity markets.

Key words: institutional component, description, standardization, regulation, typical regime of the commodity market.

\section{References}

1. Bowersox D. J. (1997). Lessons learned from the world class leaders. Supply Chain Management Review, 1(1), 61-67.

2. Krykavskyi, Ye. V. (2004). Lohistyka. Dlia ekonomistiv. Vydavnytstvo Natsionalnoho universytetu «Lvivska politekhnika».

3. Christopher, M. L. (1998). Logistics and supply chain management. Financial Times Prentice Hall.

4. Laysons, K., \& Dzhillingem, M. (2005). Upravlenie zakupochnoy deyatelnostyu i tsepyu postavok. INFRA-

M.

5. Oklander, M. A. (2008). Lohistyka. Tsentr uchbovoi literatury.

6. Chukhrai, N. I. (2009). Otsiniuvannia funktsionuvannia lantsiuha postavok: sutnist ta kontseptualni pidkhody. NU «Lvivska politekhnika». Retrieved July 05, 2021, from http://ena.lp.edu.ua:8080/bitstream/ntb/2754/1/48.pdf

7. Burkynskyi, B. V., Nikishyna, O. V., \& Tarakanov, M. L. (2021). Orhanizatsiino-ekonomichni mekhanizmy formuvannia efektyvnoi lohistyky tovarnykh rynkiv. (B. V. Burkynskyi, O. V. Nikishyna, Ed.). IPREED NAN Ukrainy.

8. Burkynskyi, B. V., \& Nikishyna, O. V. (2020). (rep.). Teoretyko-metodychnyi pidkhid do vzaiemodii ekonomichnykh interesiv sub iektiv lohistychnykh lantsiuhiv tovarnykh rynkiv. IPREED NAN Ukrainy.

9. Nikishyna, O., \& Lozova, T. (2021). Stimulating the development of cooperative logistics of the agri-food market of Ukraine in the conditions of digitalization. Selected aspects of digital society development. Publishing House of University of Technology, Katowice. Retrieved July 05, 2021, from http://www.wydawnictwo.wst.pl/uploads/files/fd7b8107149ebd5a161d53e43d7ddb2d.pdf

10. Nort, D. (1997). Institutyi, institutsionalnyie izmeneniya i funktsionirovanie ekonomiki. (A. N. Nesterenko, Trans.). Nachala. Retrieved July 05, 2021, from http://cee-moscow.com/doc/izd/North.pdf

11. Kartavenko, S. N. Opisanie i reglamentatsiya biznes-protsessov. Retrieved July 05, 2021, from https://www.cfin.ru/itm/bpr/key_realize.shtml/ Ukrainyi.

12. Tarakanov, N. L. (2013). Regionalnyie logisticheskie sistemyi: problemyi formirovaniya i razvitiya. IPREEI

13. Upravlinnia skladom. Skorochennia vytrat u skladskii lohistytsi. Retrieved July 07, 2021, from https://www.tot.com.ua/warehouse-management/

$\begin{array}{llllll}\text { 14. Upravlinnia } & \text { zakupivliamy. } & \text { Retrieved } & \text { July } & 07, & 2021,\end{array}$ from https://stud.com.ua/14279/logistika/upravlinnya_zakupivlyami

15. Perevezennia shvydkopsuvnykh vantazhiv: pravyla i umovy zberihannia.: Retrieved July 07, 2021, from https://www.cargo-ukraine.com/uk/perevezennya-shvidkopsuvnix-vantazhiv/

16. Realii rynku zbirnykh perevezen. Retrieved July 07, 2021, from https://euroshuttle.com.ua/blog/realiirynka-sbornykh-perevozok-ua/

17. Tarakanov, M. L., \& Makoveiev, A. P. (2015). Lohistychnyi faktor formuvannia dodanoi vartosti v systemi tovarnykh rynkiv. Ekonomika: realii chasu, (2), 125-130.

Received 20 July 2021

Approved 3 August 2021

Available in Internet 24.10.2021

Цитування згідно ДСТУ 8302:2015

Нікішина О. В., Тараканов М.Л. Маркетинговий вимір механізмів логістичної взаємодії у ланцюгах товарних ринків // Економіка харчової промисловості. 2021. Т. 13, вип. 3. С. 23-33. doi: 10.15673/fie.v13i3.2129

Cite as APA style citation

Nikishyna, O., Tarakanov, M., \& Zerkina, O. (2021). The institutional component of the regulation of commodity circulation in the system of commodity markets. Food Industry Economics, 13(3), 23-33. doi: 10.15673/fie.v13i3.2129 